\title{
Change in and through practice: Pierre Bourdieu, Vincent Pouliot, and the end of the Cold War
}

By Sebastian Schindler; Tobias Wille

Cluster of Excellence 'The Formation of Normative Orders', Goethe University Frankfurt, Max-Horkheimer-Straße 2, 60323 Frankfurt (Main), Germany

Email: s.schindler@soz.uni-frankfurt.de; wille@soz.uni-frankfurt.de

Please cite the published version of this paper:

Sebastian Schindler and Tobias Wille. 2015. 'Change in and through Practice: Pierre Bourdieu, Vincent Pouliot, and the End of the Cold War'. International Theory 7 (2):330359. (doi: 10.1017/S1752971915000068).

This version is free to view and download for private research and study only. Not for redistribution, re-sale or use in derivative works. (C) Sebastian Schindler \& Tobias Wille

\begin{abstract}
The end of the Cold War led to intense debates about how change happens in international politics. In this article, we argue that practice theory has great potential for illuminating this question. Drawing on Vincent Pouliot's empirical analysis of NATORussia relations after the end of the Cold War, we elaborate how change happens in and through practice. We show that post-Cold War security practices are inherently unstable, because there is a fundamental uncertainty about whether the Cold War is really over or whether the Cold War logic of bipolar confrontation still applies. Uncertainty about the meaning of the past destabilizes present practices and thus makes sudden and drastic change possible. To date, many contributions to the literature on international practices have, however, failed to grasp the inherent instability of practice. We argue that this failure is due to a particular conception of change that can be found in the works of Pierre Bourdieu. Through a close reading of Pouliot's Bourdieusian analysis of post-Cold War politics, we demonstrate the limitations of such a perspective, notably that it is unable to grasp how change originates in practice.
\end{abstract}

Keywords: international practices; practice theory; social change; Pierre Bourdieu; Cold War; NATO-Russia diplomacy 
There are no events that unequivocally point into the future.

Hannah Arendt

The end of the Cold War sparked intense debates in the academic discipline of International Relations (IR). These debates were not only about how to explain the unforeseen event, but also about what its consequences would be. John Mearsheimer (1994), for example, warned that the rise in importance of international institutions was a 'false promise', and predicted that states' quest for power and security would continue in the post-Cold War world. On the other hand, scholars like Alexander Wendt (1992, 419-422) argued that a fundamental normative transformation of international politics had taken place when Gorbachev's New Thinking ended bipolar confrontations and the Soviet Union dissolved peacefully. ${ }^{1}$ Even today, a quarter century after the momentous happenings of 1989, the debate over the significance of the end of the Cold War is not over. The consequences of the event remain uncertain (Lawson 2010). While there is some agreement about what ended in 1989 , there is much less certainty about what has begun. The end of the Cold War thus poses, in a particularly pronounced way, the question of change in international politics - of whether and how change happens, and how it can be studied and explained.

We believe that a promising answer to the question of change can be found in practice theory, a theoretical perspective that has recently attracted a lot of interest in IR. ${ }^{2}$ As we will demonstrate in this article, the study of international practices - of the everyday 'doing' of international politics - can offer a fresh angle on how change occurs. So far, however, practice theory in IR has been struggling with the problem of change. We argue that these difficulties are due to the dominance of a particular strand of practice theory that stresses the patterned and repetitive nature of practice and emphasizes the unconscious reproduction of social order. One prominent representative of this strand of practice theory, Pierre Bourdieu, has left a particular imprint on IR. Indeed, as Bueger and Gadinger point out, 'IR tends to equate the notion of practice theory with the thinking of

\footnotetext{
${ }^{1}$ Mearsheimer's (1994) and Wendt's (1992) arguments are representative of broader perspectives on the end of the Cold War in IR. For contributions that stress the continuity of power politics, see e.g. Wohlforth (1994), Walt (1997, 478f.). For contributions that argue that a fundamental normative change has taken place, see e.g. Koslowski and Kratochwil (1994), Lebow (1994).

2 Cf. Neumann (2002), Pouliot (2008), Adler and Pouliot (2011a; 2011b), Bueger and Gadinger (2014).
} 
Pierre Bourdieu', a development that is problematic since it 'reduces the spectrum and hence the potential of practice accounts for IR' (forthcoming).

In our view, Bourdieu rightly takes a central place in the debate on international practices. Many of his concepts have proven to be powerful 'thinking tools' for the analysis of international politics, ${ }^{3}$ while his model of a reflexive sociology provides a template for a more self-aware discipline of IR (Leander 2002; Eagleton-Pierce 2011; Hamati-Ataya 2013). However, like every theory, Bourdieu's theory of practice sheds light on some aspects of reality at the price of casting shadows elsewhere. In this article, we are concerned with one particular blind spot of Bourdieu's conceptual toolkit, namely its inability to grasp how change may originate from within practice itself. As generally acknowledged by practice theorists in IR, 'Bourdieu's thought is at its core a theory of domination' (Pouliot and Mérand 2013,36). At the center of this theory of domination lies the concept of habitus, which denotes a set of dispositions that orient action. Formed through past experiences, habitus conditions present practices and thereby reproduces structures of domination. An important proponent of Bourdieusian thought in IR defines habitus as the 'unconscious overtaking of rules, values and dispositions gained from an individual and collective history', which 'functions like the materialization of collective memory' (Adler-Nissen 2008, 669). It is however far from obvious how change can be explained within the logic of habitus, a problem that has been pointed out by several critics (e.g. Duvall and Chowdhury 2011, 349; Ringmar 2014, 17-20; Bueger and Gadinger forthcoming).

Our argument is that change, like stability, is a product of how practices relate to the past. We agree with theorists who assert that practices are structured by past experiences, which provide orientation for acting in the present (e.g. Hopf 2010; Neumann 2012). However, contra Bourdieu, we stress that this 'making present' of the past is marked by fundamental uncertainties. Such uncertainties can originate from large historical events like the end of the Cold War. As much as debates in the discipline of IR were marked by a fundamental disagreement on the consequences of the event, exemplified in the opposing views of Mearsheimer and Wendt, as much were post-Cold War practices themselves marked by the contestation of what the past meant in and for the present. Uncertainty about the meaning of the past destabilized present practices and thus made sudden and drastic changes possible.

We elaborate this argument through a critical re-reading of an important recent contribution to practice theory in IR, Vincent Pouliot's International Security in Practice

\footnotetext{
${ }^{3}$ Leander (2008). For an in-depth discussion of many of these tools, see the contributions in Adler-Nissen (2013).
} 
(2010). In this book, Pouliot gives a detailed account of NATO-Russia diplomacy after the end of the Cold War. While Pouliot offers an insightful historical narrative of transformations in the relations between NATO and Russia after 1992, his theoretical conceptualizations fail to grasp how precisely change happened in practice. We maintain that this failure is due to Pouliot's reliance on a Bourdieusian understanding of change. Pouliot explains social change as the result of 'hysteresis', that is, the temporary misalignment between recently transformed social structures and an 'outdated' habitus. He maintains that dispositions that were formed during the Cold War continued to guide the actions of many Russian security practitioners after 1989. Their outdated habitus generated 'quixotic' and 'out of place' behavior that made change possible (Pouliot 2010, $188,190)$. We argue that Pouliot's own empirical analysis does not support his theoretical explanation of change. Practices were unstable not because one set of dispositions was objectively outdated, but because there was a fundamental uncertainty whether the Cold War was really over or whether its logic of bipolar confrontation still applied. What was outdated was itself contested in practice.

The main goal of our intervention is not criticism for criticism's sake. Rather, we believe that it is important to understand not only the strengths but also the weaknesses of the Bourdieusian paradigm that, at the moment, plays such a prominent role in IR. One such weakness lies in the lack of a clear and convincing theoretical conception of how change originates within practice. In order to explain change in post-Cold War politics, it is necessary to move beyond Bourdieu. Our argument about the contested actualization of the past is inspired by the works of theorists that have tried to come to terms with the instability of practice, either by extending Bourdieu's original vocabulary (Bigo 2011) or by evoking other theoretical ideas, such as pragmatist critiques of Bourdieu (Boltanski 2011; Leander 2011) or poststructuralist thought (Duvall and Chowdhury 2011; Hansen 2011). Moreover, we integrate insights from studies that shed light on how past experience orients present action, such as notably the historical-anthropological theory of the event (Sahlins 1985; Sewell 2005), as well as studies of collective memory (French 2012; Edkins 2003). While these literatures help us to clarify our theoretical argument, it remains primarily grounded in Pouliot's own empirical account. The commendable clarity and transparency of Pouliot's analysis allows us to put forth our own, alternative theoretical explanation of change in post-Cold War politics.

In their concluding chapter to Adler and Pouliot's edited volume on International Practices (2011), which assembles many of the protagonists of practice theory in IR, Duvall and Chowdhury note that 'none of the chapters in this volume sheds light on fundamental changes in the international system', listing the end of the Cold War as one example $(2011,348)$. Instead the contributors to the volume focus either on incremental changes' or on how external shifts lead to changes in practice $(2011,348)$. We concur with 
Duvall and Chowdhury in their assessment that the reason for this omission lies in the current 'theoretical orientation' of IR practice theory (2011, 348f.). To elaborate where exactly the problem lies with the current theoretical orientation, we first discuss the role and place of change in Bourdieu's theory of practice. Second we demonstrate how Pouliot, due to his Bourdieusian conception of change, fails to provide a convincing theoretical explanation of change in post-Cold War politics. Third we elaborate in detail our own account of how change happens in and through practice.

\section{Pierre Bourdieu and the question of change}

The works of Pierre Bourdieu have been a major source of inspiration for scholars interested in international practices. ${ }^{4}$ Since Bourdieu himself has not elaborated a distinct theory of international politics, these scholars have adopted a range of his concepts as 'thinking tools', applying them creatively to the study of various facets of international life. As Leander points out, this creative appropriation of his toolkit is very much consistent with Bourdieu's own outlook, who was 'not trying to construct scholastic theory, theories for theory's sake', but rather was interested in developing theories that are 'useful for the understanding of concrete issues and problems' (Leander 2011, 308).

In this section, we will take a closer look at one particular thinking tool that takes a central place in Bourdieu's work, the concept of habitus. We engage with this concept in such detail, because it will help us to understand many of the problems practice theory has in explaining change in international politics. As we will demonstrate, habitus is a very useful concept if one wants to account for the reproduction of relations of domination. However, it is not the best tool to think through dynamics of social change. Consequently, accounts that try to do so struggle with its limitations.

In the following, we first discuss what the thinking tool of habitus was designed for and where its particular strengths lie, namely in explaining social reproduction while avoiding some of the perils of structuralism. Second, we argue that this specific concept is not particularly apt for another theoretical task, the task of explaining social change, even though it allows some limited insight into the conditions under which change becomes possible. Third, we discuss in how far the introduction of other concepts and particularly

\footnotetext{
4 For example Adler-Nissen (2014), Bigo (2011), Eagleton-Pierce (2012), Go (2008), Guzzini (2000), Hopf (2010), Jackson (2008), Kuus (2014), Leander (2011), Mérand (2010), Pouliot (2010), Shapiro (2002), Villumsen Berling (2012), Williams (2007), and the contributions in Adler-Nissen (2013).
} 
the notion of multiple fields can, in combination with habitus, provide a more elaborate, yet still limited explanation of social change.

\section{Habitus and social reproduction}

The concept of habitus, which Bourdieu first developed in his early work on the Kabyle society in colonial Algeria, is intended to provide a solution to an intricate theoretical question well known in IR as the agent-structure problem, the question whether we shape our own destiny through our actions or whether they are ultimately determined by larger structures (Giddens 1984; Wendt 1987; Wight 2006). ${ }^{5}$ To overcome this 'dilemma of determinism and freedom' (Bourdieu 1977, 95), Bourdieu proposes to grasp individual action as creative improvisation which is constrained by given social structures. Habitus plays a central role in this solution. As a mediating concept it allows Bourdieu to make sense of the overall continuity of social life without eliminating individual agency (Harker 1984; Swartz 1997, 212f.).

Habitus is defined by Bourdieu as 'a system of lasting, transposable dis- positions' functioning as 'matrix of perceptions, appreciations, and actions' (Bourdieu 1977, 82f.). Habitus is, in other words, a fairly stable set of dispositions that inclines actors to perceive, understand, and act upon the world in particular ways. It endows them with a 'practical sense', a 'socially constituted "sense of the game"' (Bourdieu and Wacquant 1989, 42). This practical sense is shaped by past experiences of both the individual and his or her social group. Habitus is thus 'the active presence of the whole past of which it is the product', it is 'embodied history, internalized as a second nature and so forgotten as history' (Bourdieu 1990, 56).

As a set of dispositions shaped by past experiences, habitus links practices to larger social structures. It is 'structured structure' in the sense that it is shaped by the structures of society and it is 'structuring structure' in that it generates and organizes practices (Bourdieu 1990, 53). In other words: larger social structures produce the habitus, and the habitus generates practices. The central point for Bourdieu's understanding of social reproduction is that these practices in turn tend to reproduce the given social structures. We end up with a 'system of circular relations which unite structures and practices' (Bourdieu and Passeron 1977, 203, original emphasis; cf. Bourdieu 1977, 83).

5 Bourdieu frames this question as a dispute between the theoretical positions of objectivism and subjectivism, epitomized by Claude Lévi-Strauss' structuralism and JeanPaul Sartre's voluntarism (Bourdieu 1977; 1990; cf. Brubaker 1985). 
This conceptualization of social reproduction has exposed Bourdieu to the accusation of endorsing the deterministic formula of 'structures produce habitus, which determine practices, which reproduce structures' (cf. Bourdieu and Wacquant 1992, 135f.). Rejecting this allegation, Bourdieu points out that the outlined dynamics of social reproduction, under which habitus and structure are in almost perfect alignment, are only a 'particular case of the possible', and warns us against 'unconsciously universalizing the model of the near-circular relationship of near-perfect reproduction, which is completely valid only when the conditions of production of habitus and the conditions of its functioning are identical or homothetic' (Bourdieu 1990, 63). Substantive social change, Bourdieu insists, is possible in situations when the alignment between habitus and the larger structures of society is distorted.

\section{Habitus and social change}

For Bourdieu, habitus generally tends to reproduce the social structures of which it is the product. Only when habitus and structure are misaligned, substantive change becomes possible. This raises the obvious question where such a misalignment should originate. According to King, 'the whole problem of the habitus is that it blocks any social change which Bourdieu subsequently assumes. If every individual is constrained by his habitus, then the objective conditions will simply be reproduced (by the habitus) and no social change will take place' (King 2000,428). As King correctly notes, there are other elements of Bourdieu's theory of practice that are more apt for explaining change.

Nonetheless habitus can illuminate the problem of change from an interesting angle. As we saw, Bourdieu insists that the circle of 'near-perfect' reproduction can break down when there is a misalignment between structure and habitus. Bourdieu conceptualizes this misalignment as 'hysteresis', as a lagging behind of the habitus. He borrows the concept from physics where it denotes a time lag between the exposure of a ferromagnet to an external magnetic field and the ferromagnet's own magnetization (Bourdieu 1984, $142 ; 1990,59)$. How hysteresis plays out in social practice is exemplified in Bourdieu's work on the French university system in the late 1960s. There his argument is that

the categories of perception that agents apply to the social world are the product of a prior state of this world. When structures are modified, even slightly, the structural hysteresis of the categories of perception and appreciation gives rise to diverse forms of allodoxia [misapprehension]. Classificatory schemata originating in common perception of the former state of the education system, such as the distinction between humanities and science students or between the grandes écoles and the universities, lead to representations of present reality that do not account for new realities (Bourdieu 1996, 219; cf. 1988). 
Categories of perception, which were formed under past conditions which no longer apply, lead hysteretic actors to perceive the world in a way which does not fit the 'new realities' of how the respective social context (in this case the academic field) is structured.

While the metaphor of hysteresis seems to imply that the outdated habitus will adjust after being exposed to the new 'magnetic field' of the transformed social context, for Bourdieu adjustment is just one theoretical possibility. He leaves open how individuals or groups react when their habitus and thus their deeply internalized past experiences are not matched by new social structures. A hysteretic misalignment between habitus and structure can lead either to an adaptation of the actors to the new conditions or to revolutionary struggle against the prevalent social order, it 'can be the source of misadaptation as well as adaptation, revolt as well as resignation' (Bourdieu 1990, 62; cf. $1984,165-168)$. Bourdieu thus does not formulate a theory of what happens when the circle of 'near-perfect' reproduction is broken.

The concept of habitus primarily provides an explanation of social reproduction. It can also illuminate the conditions under which social change becomes possible. Its limitations are, however, that it does neither provide an explanation for how social change unfolds, nor for how change can originate in practice. In the logic of 'hysteresis', the origins of change lie in structural shifts that render dispositions mis-aligned, not within practice itself.

\section{Fields and social change}

In the 1970s Bourdieu further elaborated his analysis of social domination, now with an explicit focus on modern, highly differentiated societies, by developing the notion of multiple fields. A field for Bourdieu is an arena in which actors struggle to improve or at least defend their position. It is 'a network, or a configuration, of objective relations' between various positions that impose different practical necessities on their respective incumbents (Bourdieu and Wacquant 1989, 39; cf. Bourdieu 1990, 66-79). In each field (e.g. the economic, artistic, or academic field), actors struggle over the distribution of and conversion rates between a field-specific mix of capitals and the associated positions and privileges.

This raises the question how the internalization of one's place in society on the one hand and struggles for position in the various fields on the other go together. As Swartz points out, 'both adaptation and distinction are two types of agency juxtaposed in the concept of habitus without their exact relationship being clarified' $(1997,114)$. Bourdieu maintains that the struggles in a field tend to reproduce its structure, including 'even those struggles aimed at transforming it' $(1984,156)$. He argues for example that the efforts by which the 
members of a social class try to improve their relative position tend to be 'compensated for (and so cancelled out ordinally) by the reactions of the other classes, directed towards the same objective' (Bourdieu 1984, 157). Both adaptation and distinction thus pull in the same direction, namely the reproduction of an unequal social order.

Dividing the social in various fields in principle allows for a more dynamic analysis of social change. In the refined model, practices are generated by the intersection of habitus and field. Individuals with historically formed dispositions and endowed with a particular set of capitals, when confronted with the structure of a particular field, tend to act in specific ways. Since social actors can enter and leave fields and be positioned in several of them at once, this opens the theoretical possibility that a habitus that has formed in one field is confronted with another field to which it is not aligned. For Bourdieu, these dynamics primarily serve as an explanation for the homogenization of domination across several fields. However, theoretically the resulting tensions could also trigger social change (Swartz 1997, 211-214), a possibility that has indeed been considered in IR (Bigo 2011, 240; Leander 2011, 305; Neumann and Pouliot 2011, 113).

While Bourdieu's refined theory of practice centered on the notion of multiple fields leaves more space for social change, the principal problem remains the same. The sources of change always lie somewhere else, outside the field in which it unfolds. It is there that actors acquire a habitus that later causes hysteresis. As Giroux points out,

where the conceptual possibility for resistance does appear in Bourdieu's work - that is, in the mismatch between one's habitus and the position one occupies - the foundation for such action rests not on a notion of reflexivity or critical self consciousness, but on the incompatibility between two structures - the historical structure of the disposition and the historical structure embodied in the institution (Giroux 1983, 271).

The concept of habitus can, in other words, not explain how change originates in practice itself. This is not a shortcoming of the concept as such. Habitus is, after all, a great thinking tool to account for the general continuity of social life without fully eliminating agency. Complemented with the concept of field, habitus provides a convincing explanation for how social domination is sustained across various domains in complex con- temporary societies. However, thinking about change through the lens of habitus forces the theorist to conceive of change not as something that is inherent in practice, but as something that is triggered by a misalignment originating outside of the specific practices under study. As we will see in the next section, in which we provide a detailed reading of Pouliot's International Security in Practice (2010), it is difficult to account for the dynamics of postCold War politics with the Bourdieusian conceptual toolkit. 


\section{Vincent Pouliot and change in NATO-Russia relations}

The end of the Cold War triggered intense debates among IR theorists about the possibility of change in international politics. It is therefore no surprise that the event and its consequences also occupy a central place in the Bourdieusian scholarship on international practices. Most Bourdieusian scholars interpret the end of the Cold War as a major transformation of the structures of the international system and in particular the field of international security. ${ }^{6}$ Pouliot begins his historical analysis of post-Cold War politics with the observation that 'the end of the Cold War was a watershed in the history of international security' (Pouliot 2010,150). Williams writes that 'the demise of the Cold War entailed a shift in the field of security practices', which rendered possible 'the exploitation of a new set of generative possibilities already contained within the habitus of security actors and institutions' (Williams 2007, 40; similarly Villumsen Berling 2012, 471). Crucially, in the eyes of these authors, the end of the Cold War did not only affect the macro-structures of the international system, it also 'transformed the social fields in which security and defense officials live their lives' (Mérand 2010, 363).

In the remainder of this article, we will assess practice theory's potential for making sense of the changes that happened after the end of the Cold War. We argue that practice theorists have so far overlooked a crucial mechanism through which change happened in post-Cold War international politics. In our view this omission is due to the specific, Bourdieusian conception of change we have elaborated in the last section, a conception that is based on the distinction between objective structures and subjective dispositions. As we have indicated, Bourdieusian scholars tend to interpret the end of the Cold War as a 'field change' that led to various adaptations and changes in the dispositions of practitioners. Yet as we will show, post-Cold War practices were themselves characterized by intense debates about what this 'field change' consisted in. Change happened because the significance of the past for the present was negotiated in practice.

We elaborate this argument on the basis of one significant contribution to international practice theory, Vincent Pouliot's International Security in Practice (2010, thereafter ISiP). We engage with Pouliot's book in such detail because of its rich grasp of changes in the political relations between NATO and Russia after the end of Cold War. In this section we

\footnotetext{
6 One could also imagine a Bourdieusian interpretation of the events of 1989 that emphasizes the continuity of global patterns of domination and thus calls into question the widely shared conviction that the end of the Cold War marks a transformation of global scale. For a Bourdieu- inspired theory of habit that stresses continuity, not change, and might allow for such a conclusion, cf. Hopf (2010).
} 
will critically re-assess Pouliot's theoretical claims in light of his empirical analysis. ${ }^{7}$ Our main finding is that Pouliot's theorization of change fails to capture a crucial mechanism that is clearly evident in his empirical narrative. In the following we first reconstruct Pouliot's empirical account of change in NATO-Russia relations after the end of the Cold War. Second we present Pouliot's theoretical explanation of change. Third we argue that this theoretical interpretation fails to reflect his empirical insights into how change actually happened.

\section{Change in NATO-Russia relations, 1992-2008}

For Pouliot (ISiP, 150-161) and many other Bourdieusian scholars of international practices, the end of the Cold War led to a fundamental transformation of the field of international security. The dominant mode of seeking security changed from 'external' to 'internal' (Gheciu 2005, 4-7). During the Cold War, East and West tried to maximize security through external alliance-building and power-balancing. After the Cold War, Russia and NATO members considered states' internal institutions as crucial for security. As Russian foreign minister Andrey Kozyrev said in 1992, one of the basic mainstays of Russian foreign policy should be that 'respect for human rights and fundamental freedoms is an essential com- ponent of peace' (quoted in ISiP, 157). This attitude led to a harmonious period of NATO-Russia relations. Both sides agreed on the new rules of the international security game, according to which 'cultural-symbolic not materialinstitutional resources formed the sinews of power' (ISiP, 151). Russian leaders by and large accepted Western democracies' cultural- symbolic superiority (ISiP, 158).

However, the agreement came to a sudden end when, on 1 December 1994, the NorthAtlantic Council declared that NATO would begin 'a process of examination inside the Alliance to determine how NATO will enlarge' (quoted in ISiP, 167). In Pouliot's analysis, NATO's decision to enlarge took many senior officials by surprise, including the US Secretary of Defense - and it came as a 'huge blow' to the Russians (ISiP, 167). While there had been talk about the possibility of NATO enlargement prior to the NATO communiqué of 1 December, President Clinton had promised to Russian President Yeltsin that there would be 'no surprises, no rush, and no exclusion' (ISiP, 167). And also most observers believed that enlargement was still off the agenda (ISiP, 167). With the NATO communiqué, it seemed, however, that the open question was not whether, but how NATO would enlarge.

${ }^{7}$ Such a critical re-assessment is facilitated by Pouliot's 'sobjectivist' methodology which first recovers 'subjective' meanings and then stepwise makes them more 'objective' by contextualizing and historicizing them (ISiP, ch. 3; cf. Pouliot 2007). 
For Russian leaders and security practitioners (i.e., diplomats, officers, experts, etc.), NATO's decision to enlarge eastwards violated the new rules of international security. Exclusive alliance-building, and not the inclusive principles of the Conference for Security and Co-operation in Europe (CSCE), seemed to guide NATO's actions (ISiP, 168-174). Pouliot shows how many of Russia's tougher steps were a consequence of, or at least chronologically followed, NATO's decision: an alarming speech by President Yeltsin in early December 1994, in which he warned that Europe was 'risking encumbering itself with a cold peace' (quoted in ISiP, 168); later in the same month, the invasion of Chechnya, which 'cannot be said to have been the catalyst of the enlargement process because military orders were given after NATO's decision had been publicly announced' (ISiP, 176); and more generally, the re-emergence of the 'Russian Great Power habitus', visible in calls for 'equality, multipolarity, spheres of interest and balance of power' (ISiP, 179). Pouliot summarizes: 'The gist of my argument consists in linking the revival of Great Power dispositions in Russia to NATO's practices with regard to the double [i.e., functional and geographical] enlargement' (ISiP, 179).

The December 1994 enlargement decision was a 'turning point' or 'critical juncture' (ISiP, 161) that substantially altered the practices of NATO-Russia relations. The post-Cold War 'honeymoon' from 1992 to 1994, characterized by a consensus about the dominance of the internal mode of pursuing security, was followed by a 'rough patch' during which both sides thought of their relationship more in terms of a security dilemma than in terms of inclusive security. Pouliot describes a number of specific practices that illustrate both sides' growing distrust (ISiP, 182-192). The Russian government, for example, elaborated a new military doctrine that stressed external security, decided to increase military forces at Russia's Western borders, and deployed obstructionist negotiation strategies (ISiP, 188-191). The 'rough patch' culminated in the dispute over NATO's intervention in Kosovo in 1999, which nearly led to a military confrontation when Russian troops rushed to seize the airport of Pristina before NATO could reach it, and NATO's Supreme Commander Wesley Clark ordered to prepare a military attack - an attack that was averted when the British General Michael Jackson refused to execute the orders (ISiP, 201).

However, the period of 'Cold Peace', which had begun so abruptly in December 1994, was not as stable as it might appear from the viewpoint of today's rather tenuous relations between NATO and Russia. It was interrupted by a second 'honeymoon' - which was, according to Pouliot, triggered by an 'exogenous shock' (ISiP, 211): the attacks of 11 September 2001. Pouliot argues that 9/11 fundamentally transformed the structures of the international security game: 'hard [external] security was to take precedence over the soft agenda of security from the inside-out' (ISiP, 212). NATO thus tuned down its criticism of Russia's measures against 'terrorists' in Chechnya (ISiP, 212). The change is 
visible also in the attitudes of the Russian leadership, who had vigorously opposed a further round of NATO enlargement before September 11. In October 2001, however, President Putin suddenly stated he could revise his opinion on the matter if NATO transformed itself into a political organization (ISiP, 216). Guided by their newly found sense for the integrative, positive sum character of security, NATO and Russian practitioners subsequently engaged in a number of common practical activities, such as Operation Active Endeavour, a joint military initiative aimed at fighting terrorism in the Mediterranean (ISiP, 125). As with the December 1994 rupture, 9/11 thus brought about an abrupt change in the practices of NATO-Russia relations.

The second 'honeymoon' did not last long either. The US invasion of Iraq in 2003, which violated, in the views of Moscow, the principle of state sovereignty; NATO's acceptance of seven new member states in 2004, including the Baltic states bordering Russia; and other events described in detail by Pouliot (ISiP, 215-221) led to a return of the logic of bipolar confrontation, marked notably by Russia's intervention in Georgia in 2008, which in the end even resulted in the suspension of the NATO-Russia Council (NRC), the site of practice to which Pouliot dedicates a whole chapter of his book (ISiP, ch. 4).

This brief summary of Pouliot's dense historical analysis shows that the practices of NATO-Russia relations were quite unstable and subject to abrupt, substantial transformations. The crisis of December 1994, the attacks of 9/11, and a further round of NATO enlargement in 2004 fundamentally changed, according to Pouliot's narrative, many specific practices, such as cooperative initiatives and joint military operations. These events had a strong influence on the practical sense that guided and generated practices. NATO and Russian practitioners' dispositions, i.e., their habitus, shifted back and forth from internal to external security, from a more cooperative to a more conflictive approach to security. How can one make sense of these changes? The remainder of this section describes Pouliot's theoretical answer to this question, and argues that this theoretical answer fails to grasp how change happened in practice.

\section{Change as effect of 'hysteresis'}

Following Bourdieu, Pouliot identifies 'hysteresis' as the main source of social change. When the objective structures of a field and thus the positions of the actors are transformed, their dispositions may lag behind. In this case, their habitus is out of tune, it is 'not homologous to intersubjective rules of the game and positions in the field' (ISiP, 49). Pouliot claims that the misalignment between objective position and subjective disposition 'weakens social order and domination patterns and opens the door to social change' (ISiP, 49). How this social change unfolds is not further specified, except for the claim that the out-of-tune actors 'exhibit awkward practices' and 'behave out of place' 
(ISiP, 48). Like Don Quixote fighting windmills, these actors 'do not behave in tune with commonsense' (ISiP, 48). Hysteresis effects are 'Don Quixote effects' (ISiP, 48). ${ }^{8}$ Quoting Bourdieu, Pouliot writes that the quixotic practices generated by an outdated habitus are 'objectively ill-adapted to the present conditions because they are objectively adapted to conditions that no longer obtain' (Bourdieu 1990, 62; quoted in ISiP, 48).

In Pouliot's theoretical explanation of change in NATO-Russia relations, the end of the Cold War constitutes the main, field-changing event that transformed the rules of the international security game (ISiP, 150-161). With the end of the Cold War, the external mode of pursuing security gave way to the internal mode, and the importance of culturalsymbolic capital increased, while the importance of material-institutional capital decreased (ISiP, 148-149). Yet the players' dispositions lagged behind: They were historically formed in the Cold War, and still had to adapt to the new situation.

Pouliot argues that this lagging behind, or hysteresis, occurred only on the Russian side. NATO's habitus was not outdated, it was '"naturally" in tune with the order of things' (ISiP, 212), because NATO was the dominant player in the new order, in abundant possession of the now prevalent type of capital. On the other hand, the Russian practices directed against NATO - 'counterproposals, hindrance, soft balancing and veiled threats' - are described by Pouliot as 'quixotic' and 'out of place' (ISiP, 188-191). Russia's 'age-old' (ISiP, 174) Great Power habitus, which allegedly generated the oppositional practices, did not correspond to Russia's objective position in the field after the end of the Cold War (for a similar argument, cf. Neumann and Pouliot 2011, 132-135). The empirical changes Pouliot describes, as summarized above, are hence explained as hysteresis effects, that is, as effects of a lag between Russia's subjective disposition and its objective position. Yet as we intend to show in the following, this explanation does not fit Pouliot's own empirical analysis.

\section{Why change in NATO-Russia relations cannot be explained with hysteresis}

The changes of NATO-Russia relations Pouliot describes empirically are not explained by his theoretical conceptualization. Consider the first major change Pouliot analyzes: the relatively abrupt turn to practices of the external mode of seeking security following NATO's decision for enlargement in December 1994. In Pouliot's empirical analysis, the argument that this change resulted from NATO's action is crucial. It is the 'gist of my [Pouliot's] argument' that NATO enlargement brought about the 'revival' of Russian Great Power dispositions (ISiP, 179), an argument Pouliot elaborates over many pages (ISiP,

\footnotetext{
${ }^{8}$ Pouliot adapts the example of Don Quixote as hysteretic actor from Bourdieu who in turn borrows it from Karl Marx (cf. Bourdieu 1990, 62).
} 
161-182). 'The brunt of change was not of domestic origin' (ISiP, 176), but it resulted from Russia's resistance against NATO’s enlargement, which many Russian practitioners perceived as motivated by NATO's interests in the hard, external security that had characterised the Cold War (ISiP, 168-174). Russia took a tougher stance on many cooperative issues and reverted to practices of exclusive security maximization, because Russian leaders thought that NATO was doing the same.

The problem here is that the 'gist' of Pouliot's empirical argument is not reflected in his theory. Empirically, resistance against NATO's decision for enlargement led to Russia's tough stance. Theoretically, however, Russia's practices of pursuing external security are supposed to be generated by an outdated practical sense. But why did the alleged lag between Russia's dispositions and its position begin to have effects only in December 1994? Why was there, as Pouliot (ISiP, 155-161) ascertains, a strong homology of dispositions and positions directly following the end of the Cold War? Pouliot's Bourdieusian vocabulary does not capture why a change of habitus happened in the weeks and months following NATO's decision from December 1994, rather than directly after the end of the Cold War. In theory, the Russian habitus should have caused friction as soon as the field changed and Russian practitioners' now 'outdated' dispositions ceased to provide guidance under the altered circumstances of the post-Cold War world. In practice, however, a conflict only arose when Russian elites began to doubt the intentions behind NATO's actions in December 1994.

Also Pouliot's explanation of the subsequent changes in NATO-Russian relations - the beginning of a second 'honeymoon' after the attacks of 11 September 2001 and the deterioration of relations in 2003/2004 - suffer from a similar problem. In Pouliot's account, 9/11 is described as an 'exogenous shock' that abruptly transformed the field of international security (ISiP, 211). But the theoretically surprising consequence of this transformation is not hysteresis, not a lag between cause and effect. It is the sudden appearance of homology, of an alignment between positions and dispositions (ISiP, 212). Both NATO and Russian practitioners now shared an external understanding of security, according to which Al Qaeda and 'Islamist' forces in Afghanistan, Chechnya, and elsewhere were the main threats to international security (ISiP, 212-213). Only in 2003 and 2004, when the United States invaded Iraq and the Baltic States joined NATO, Russia returned to what Pouliot describes as hysteretic practices (ISiP, 219-221). It was, once again, the Russian perception of NATO's actions - and not a shift in the objective structure of the field - that led Russia to oppose NATO domination.

Pouliot's analysis shows that there was a considerable instability in the practices of NATO-Russia relations after the Cold War. The practices changed in connection with certain events such as the attacks of 11 September 2001 and NATO's enlargement decisions of 1994 and 2004. In particular, Pouliot demonstrates that the deterioration of 
relations following the two rounds of NATO enlargement originated, to a considerable degree, from Russian elites' belief that NATO did not play according to the new rules of the international security game. NATO appeared to threaten Russia through military expansion, rather than to integrate the former Cold War adversary into its alliance. Pouliot's theoretical explanation, however, fails to capitalize on these empirical insights. His Bourdieusian concepts lead us to expect that 'outdated' behavior is the effect of a hysteretic habitus, i.e., of dispositions that continue to guide actions despite the disappearance of the field in which they were once formed. But Russian leaders engaged in allegedly 'outdated' practices not because they were disoriented and mistook windmills for giants. They chose to oppose NATO in 1994 and in 2004 (and not in 1992 or 2001), because NATO's own actions could indeed be seen as embodying the Cold War logic of external security. After all, even politicians and experts in NATO countries feared that enlargement without Russia might be perceived as an act directed against Russia (ISiP, 172-174).

In his careful and dense historical analysis, Pouliot demonstrates that change in NATORussia relations was not the effect of an external structural transformation. Rather, it was enabled by an inherent feature of practice: the possibility to contest whether a specific act is true to a past event ${ }^{9}$ and the social order established by it. The very assumption that grounds Pouliot's Bourdieusian theory - that certain 'outdated' acts enable change - was thus at stake and contested in practice. Pouliot's own empirical analysis makes clear that the practices of NATO-Russia relations were characterized by a disagreement over which acts were outdated and which not, and that this disagreement over what is outdated rather than the objective fact of out- datedness - made change possible. The next section will take this insight as a starting point for elaborating how change happens in and through practice.

\section{Change in and through practice}

In the previous two sections we have reconstructed how Bourdieu understands social change and demonstrated that Pouliot's application of this under- standing to post-Cold War politics fails to explain how and when change happened. In this section we will elaborate an alternative practice-theoretical understanding of change. The core idea of our argument has been sketched out already at the end of the last section. Change originates in practice because the meaning of past events is open to contestation and reinterpretation.

9 This formulation is inspired by Alain Badiou (2001, ch. 4), who stresses that events are followed by a 'truth process', that is, a negotiation of what it means to be true to the event. 
For Bourdieu and Pouliot, habitus entails an 'active presence' of the past (Bourdieu 1990, 56; ISiP, 31). Yet, as we will show in this section, making the past present can be a contentious process. Indeed, as we will demonstrate, NATO and Russian security practitioners live and act in a world in which the relationship of present practices to the past is highly uncertain. There is no certainty about whether the New Thinking that ended the Cold War really prevails in the present or whether old Cold War categories continue to be applicable. Practices are unstable because their relationship to the past is not fully settled. Change happens through a negotiation of how the present relates to the past.

In this section, we elaborate this point empirically, based on Pouliot's analyses in International Security in Practice, yet we also reference theorists who have formulated insights that support our argument. We begin our elaboration with a re-reading of the fourth chapter of Pouliot's International Security in Practice, which precedes the historical analysis discussed above. In this chapter, Pouliot undertakes a 'practice analysis' of the NATO-Russia Council (NRC) in 2006. We first show that the practices in the NRC, as Pouliot describes them, are characterized by an inherent instability. Second we demonstrate that this instability originates from a contested relationship to the past, and particularly to the end of the Cold War. Third we argue that this contestation has been a crucial mechanism of change in NATO-Russia relations since 1992.

\section{The inherent instability of practice}

In the fourth chapter of International Security in Practice, Pouliot describes the practices in the NATO-Russia Council (NRC) - a cooperative forum set up in 2002 to discuss security issues and joint projects between NATO and Russia. Pouliot here tries to refrain from 'superimposing an analytical framework onto interview data' and instead attempts to recover 'the subjective meanings that comprise the logic of practicality' at the NRC in 2006 (ISiP, 95). His 'practice analysis' draws on sixty-nine interviews with security practitioners, and the explicit intention is to 'let practitioners speak for themselves with as little interference as possible' (ISiP, 95). In this 'unfiltered' account of the practices of NATO-Russia relations, the inherent instability of practices is particularly evident.

This instability is reflected in how Pouliot structures the chapter. The chapter's stated aim is to describe how practitioners in the NRC interact in practice and to analyze their practical sense as it is shaped by and expressed in the routines of everyday negotiations. Pouliot examines three specific aspects of practitioners' subjective dispositions which all have to do with their sense for diplomatic conflict resolution: their dispositions regarding the use of military force, the handling of disputes, and daily institutional cooperation. Pouliot deals with these three aspects in three separate sections of the chapter. In none of these sections he comes to a clear-cut, unambiguous conclusion. Instead each of the three 
sections is divided into two sub- sections, in which Pouliot argues that there is considerable trust in each other's peaceful, non-military intentions, but also a 'latent mistrust' (ISiP, 99-104, 104-111); that there is a normalization and routinization of dealing with disputes, but also a fear that dispute settlement mechanisms might suddenly be cancelled (ISiP, 112-118, 119-122); and that there is growing experience with 'doing stuff together', but also clash of organizational cultures (ISiP, 123-131, 131-140).

In none of the sub-sections of the fourth chapter Pouliot is able to reduce the dispositions of NRC practitioners' habitus to one principle. This is also evident in his summary finding that diplomacy was 'a normal but not a self- evident way to solve disputes in RussianAtlantic dealings' (ISiP, 96). Pouliot's practice analysis thus shows that the habitus of NRC diplomats is split and multiple. Their habitus contains conflicting dispositions, dispositions that contradict each other: there is trust but also distrust; there is routinization but also fear of interruption; there is experience with doing stuff together but also the experience that everyone does stuff differently. Habitus is, as Bigo puts it, 'shattered, more often contradictory than systematic, and has multiple and heterogeneous facets' $(2011,242)$.

The conflicting dispositions of NRC practitioners render the actual 'doing' of NATO-Russia relations unstable. This instability is visible in how practitioners talk about their everyday practices. In the various sub-sections of the fourth chapter we see that the same practical activity can have different meanings - as Duvall and Chowdhury stress, 'the meaning of practices can be multiple and even contradictory' $(2011,345)$. In the NRC, this finding applies even to the most basic practical activity: everyday negotiations. For some practitioners, such as a Russian official, everyday participation in the NRC negotiations means that 'Russia sits around the table like any other country. It is a member of the family' (quoted in ISiP, 127). But in another subsection, Pouliot tells us that a 'profound feeling of exclusion [...] was articulated throughout my interviews with Russian practitioners' (ISiP, 121) - as one of them said, 'they're inside the tent and we're outside' (quoted in ISiP, 121).

The practices at the NRC are irreducible to one practical sense and one practical logic. The same practical activities are suspended between different, even conflicting logics. To understand this instability, it is necessary to move beyond the Bourdieusian model of social reproduction. As pragmatist critics of Bourdieu have pointed out the notion of action is only really meaningful against a backdrop of uncertainty, or at least with reference to a plurality of possible options' (Boltanski 2011, 22; cf. Leander 2011, 304305). Similarly, Duvall and Chowdhury have emphasized that 'the possibility of polysemy is a structural necessity of practice', since practice takes place within a web of differentiated meanings (2011, 345; cf. also Hansen 2011). 
Our analysis in this subsection provides empirical support for these arguments that stress the instability of practice. That Pouliot's empirical analysis, written to bolster a Bourdieusian argument, demonstrates how unstable and polysemic practices actually are, further strengthens our case. In the following we make a specific suggestion for a better theoretical explanation of practices' inherent instability. We argue that this instability results from how practices relate to the past.

\section{The contested actualization of the past}

Within the Bourdieusian model of social reproduction, there are two possible explanations for why actors display conflicting dispositions (cf. section on Bourdieu). Either the structures of the field have changed and the dispositions of some actors lag behind (hysteresis), or some actors have entered the field who have acquired their habitus in another field (cf. Bigo 2011, 240; Leander 2011, 305; Neumann and Pouliot $2011,113)$. In both scenarios, tensions arise because different actors, through their habitus, actualize different pasts: in the case of hysteresis, the distant past that informs 'outdated thinking' versus the recent past that informs 'updated thinking'10; and in the case of actors entering a field, the past of the field from which the actors come versus the past of the field into which they enter. However, as we will demonstrate in the following, both Bourdieusian accounts equally misapprehend the origins of the inherent instability described above. The practices at the NRC were unstable not merely because the actors actualized different pasts, but because they actualized the same past differently.

In the interviews Pouliot quotes in the fourth chapter, NRC delegates, officers and experts constantly speak about what they did and what happened to them in the past. Their practical sense clearly integrates, as Bourdieu describes it in one of his definitions of habitus, their past experience (Bourdieu 1990, 56). Yet these practitioners often interpret the past they share quite differently. They draw different conclusions from the same past events. This difference in interpretations of the past is particularly evident for NATO's enlargement, which Pouliot's interviewees understand as securing democracy and human rights, but also as an exclusive, anti-Russian act that gives rise to distrust (ISiP, 107). NATO enlargement is thus given different meanings, it is made to speak to different conceptions of security (internal and external), conceptions that inform present action. As Marshall Sahlins puts it: 'The event is inserted in a preexisting category, and history is present in current action' $(1985,146)$. That this making present of the same history was contested, that it contributed to producing the instability we have described above, is palpable not only in the statements NRC practitioners make about NATO enlargement, but

\footnotetext{
10 We owe this formulation to one of the anonymous reviewers.
} 
also about other past events. It is palpable, for instance, in how they talk about Russia's participation in NATO's anti-terror operation Active Endeavor in 2006, which is described as an example of strengthened cooperation (ISiP, 125), but also as 'a great intelligence gathering' for the Russians (quoted in ISiP, 138). The same past is made present in different and, crucially, conflicting ways.

The past event that is without doubt mentioned most often in the quotations from Pouliot's interviews is the Cold War, referred to in various constellations ('Cold War logic', 'the end of the Cold War', 'post-Cold War'). It seems to be difficult, or even impossible for the interviewees, to speak about what they presently do, or have done since 1989, without an explicit or implicit reference to the Cold War. And when one examines the ways the practitioners relate the Cold War to their present activities, one sees that this relationship is not unambiguous and straightforward, but that it is a bone of contention, something that needs to be evoked time and again, because the impact of the event is both so crucial and so uncertain.

Many practitioners seem to feel the need to affirm that what they are doing has clearly left behind the Cold War and its categories of thinking and acting. For example, the routine consultation mechanisms of the NRC are portrayed by an American delegate as 'a bridge to Russia' and 'the proof that this Alliance is no longer directed against Russia' (quoted in ISiP, 128). Both senior Russian and NATO officials claim that the way disagreements are handled has substantially changed since the Cold War ended: 'Now we will sit down, next week, and discuss the issue, [...] but we are not afraid of war', a Russian official says (quoted in ISiP, 101). And a senior member of the NATO Secretary-General's office asserts that 'both sides are much freer to talk about what's on their mind. In the Cold War it was simply impossible to go there' (quoted in ISiP, 116).

But then there is also the fact that, as Pouliot summarizes, 'on both sides, accusations of 'outdated, Cold War-like thinking' abound' (ISiP, 106). For instance, a French delegate claims that the Russians behave as if they had not yet entered the post-Cold War period: 'They come from the Warsaw Pact where they were the kings' (quoted in ISiP 139). And a German officer asserts, referring to the difficulty of informal exchanges with the Russians, that 'the Cold War is not over' (quoted in ISiP, 138). On the other hand, a Russian official explains that NATO members have drawn false conclusions from the end of the Cold War: 'The United States keeps lecturing Russia. This is not welcome. It looks like diktats for losing the Cold War. But Russia didn't lose the Cold War: it was an internal choice' (quoted in ISiP, 138).

Practitioners' obsession with talking about the Cold War, and with linking what they do to the past, shows that habitus is indeed an 'active presence of the whole past of which it is a product' (Bourdieu 1990,56). But the way in which the past is actualized in present 
practice does not consist in a mere reproduction. Rather, this actualization is contested and in NRC practices, it is contested in a quite fundamental sense. The practical activities that actualize the past - how one solves disagreements, for example - are caught between different relationships to the past. They are suspended between being distinctly different from the past, a proof that things have changed, and being a mere continuation of the Cold War in another form, a proof that the Cold War is not over. None of these practices is thus capable of creating complete certainty about whether the Cold War has really ended. With Derrida (1982), one can describe the Cold War as the origin of a différance, of both difference and deferral: The Cold War is, in the NRC, both what is clearly different from the present and what is permanently deferred, because it can never entirely end.

At the NRC, the relationship between past and present is contested. There is uncertainty about the time practitioners live in, about how the past continues into the present. And there is, crucially, no evidence that one interpretation of the past, or one consequence that is drawn from it for present practice, clearly dominates; that, for instance, practitioners who claim that the logic of the Cold War still prevails are clearly dominated by those who think that the end of the Cold War has changed the rules of the game. None of these views is necessarily the perspective of a Don Qixote, disoriented and lacking common sense. Instead the crucial insight is that both perspectives on the past are made present in practice, that they both provide orientation for what is presently done, while, nonetheless, standing in permanent conflict. The two conflicting perspectives mark the same practices and thereby render them unstable and subject to change.

For the purpose of our argument, we are not concerned with the truth of descriptions of the past, ${ }^{11}$ but with how practitioners use such descriptions to make sense of the present. The meaning of history and the processes through which it is brought into the present are also of central concern to studies of collective memory (Halbwachs 1992). Scholars in this tradition have enquired how memories of the past are linked to and taken up in various sites of memory: 'language, monuments, memorials, rural landscapes, urban environs, testimonies, and embodied performances' (French 2012, 340; cf. Nora 1989). Jenny Edkins, an IR scholar who has extensively engaged with practices of memory, points out that 'remembering is intensely political: part of the fight for political change is a struggle for memory' (Edkins 2003, 54). ${ }^{12}$ In Pouliot's analysis of the dispositions of NRC

11 On the question how the availability of new descriptions in the present affects the truth of statements about the past, see the recent debate surrounding Ian Hacking's work on 'indeterminacy in the past'; Hacking (1995, ch. 17), Gustafsson (2010), Roth (2012).

12 For two further insightful studies of collective memory in IR that, like Edkins, stress the importance of traumatic events, see Zehfuss (2007) and Auchter (2014). 
practitioners, it is evident that multiple versions of history are present without any one clearly dominating. How these practitioners remember the past - and this is the crucial point from a practice-theoretical perspective - has important con-sequences for how they act in the present.

The question of how the past relates to the present is negotiated in practice and it finds, in concrete moments and at concrete places, definite answers: answers like the ones given by practitioners to Pouliot's questions. Our more general point in this section is that these answers are often contested. Specific diplomatic initiatives, the enlargement of alliances, or terrorist attacks are judged in contested ways, as creating mistrust or trust, as continuing the Cold War or confirming that it is over. Which answer prevails time and again has to be settled in and through practice. And precisely in moments when doubts loom particularly large, when contestation is particularly strong, the likelihood of change will be particularly high. A more general change of practice, toward one or another actualization of the past, then becomes possible. As we will demonstrate in the next subsection, such changes in and through practice took place at the crucial 'turning points' or 'critical junctures' Pouliot identifies in his historical analysis.

\section{Explaining Change in NATO-Russia relations}

When the North-Atlantic Council issued its enlargement communiqué in 1994, when airplanes crashed into the World Trade Center in 2001, and when the Baltic states joined NATO in 2004, dramatic changes in NATO- Russia relations ensued. From the perspective of the specific practices that changed after these historical events, the past was, in one sense, always external. Yeltsin's Cold Peace speech in December 1994, or common military exercises after $9 / 11$, did not alter the text of the enlargement communiqué or undo the collapse of the World Trade Center. And yet the way in which the always external past is integrated into the present is never fully settled. Large historical events are usually followed by intense negotiations of what they mean. In the historical-anthropological theory of the event developed by William Sewell and Marshall Sahlins, this process of negotiation is understood as a crucial mechanism of change (Sahlins 1985, 120-135; Sewell 2005, 236-244).13

In the sense of Sewell and Sahlins, the externality of the past does not prevent it from being negotiated - and altered - in the present. This negotiation transforms the meaning of past events and, crucially, 'reorients' the conditions of action in the present (Sewell 2005, 219; cf. Sahlins 1981, 8). Through the contested actualization of the past, present

13 In other theoretical vocabularies, this process has been described as 'truth process' (Badiou 2001) or as 'politics of the event' (Lundborg 2012). 
practices change. This insight provides the key to understanding the abrupt transformations of NATO-Russia relations after the end of the Cold War. The crucial mechanism of change was, as Pouliot's historical analysis shows, the negotiation of the meaning of the past for and in the present.

At the beginning of the 1990s, the relationship between East and West was characterized by unknown euphoria. Former enemies had become friends; security had become mutual and integrative, instead of exclusive and zero-sum. Yet this did not mean that the Cold War conception of security had entirely disappeared from practice. This other conception was not objectively outdated; it was made present even in those acts that most strongly ascertained that the Cold War was over. Or rather, the strong emphasis on integrative, post-Cold War security was necessary precisely because the risk of a return of the old categories was an ever-present possibility, palpable in feelings of doubt and, sometimes, explicitly articulated in objections.

One practitioner who clearly perceived the instability inherent in the new order was Andrei Kozyrev, Russian foreign minister between 1991 and 1996. In an article published by Foreign Affairs in spring 1994, from which Pouliot quotes at length (ISiP, 69-70), Kozyrev describes how NATO had threatened the Bosnian Serbs with air strikes in February 1994, without first consulting Russia. Kozyrev notes that

the initial lack of consultation and coordination meant that first both sides had to run the risk of returning to the old benefactor-client relationship that had played such a pernicious role in the regional conflicts of the Cold War era (quoted in ISiP, 170).

Kozyrev was thus well aware that, already in the beginning of 1994, a return of the old categories was possible. The threat against the Bosnian Serbs, which for many NATO officials expressed a new kind of security (because it was applied for humanitarian reasons), ran the risk of enacting the old kind of security (because it was made without consulting Russia). This risk materialized in Kozyrev's own doubts and, possibly, more cautious actions as foreign minister. And it materialized even stronger and with more pervasive effects later in 1994, when the North-Atlantic Council issued its communiqué stating that NATO would enlarge.

The Russian foreign minister Kozyrev and other Russian decision-makers perceived the NATO enlargement decision as a return to a logic of confrontation typical of the Cold War (ISiP, 168-174). The gist of Pouliot's historical argument is that it was this perception that motivated the sub- sequent changes in Russian policy, as they became apparent in Yeltsin's warning of a 'Cold Peace', the invasion of Chechnya and the issuing of new military doctrines which were, in turn, perceived by the West as a manifestation of Cold War thinking (ISiP, 174-191). Each of these events - NATO enlargement, Yeltsin's speech, Western reactions - casts a different light on previous happenings. Each action did not 
merely repeat the past, it also altered the meaning of the past and thereby reoriented present possibilities for action. In this sense, change was inherent in how practices brought the past into the present.

As with NATO's enlargement, the attacks of 9/11 led NATO and Russian practitioners to re-evaluate the meaning of their shared past. Both sides came to see international terrorism as a crucial threat to their security. This allowed them to reconsider what certain past events meant for the present. Thus the Russian 'anti-terrorist' operation in Chechnya suddenly appeared, for Western practitioners, less as proof for Russia's backwardness than as indication that both sides faced, in the present, a similar challenge (ISiP, 211-212). Even a political enlargement of NATO was, at one point, considered acceptable by Russian decision-makers (ISiP, 216), until other events shed, once again, a new light on the past. The war on Iraq and NATO planes patrolling at the Russian border created a new skepticism about the 'times we live in:' the logic of bipolar confrontation returned (ISiP, 215-221). Every social doing thus comprised the potential to change the meaning of the past, and with it, the interpretation of the present. Through this process, practices changed.

In our interpretation of post-Cold War politics, we have demonstrated that changes of practice resulted from the contestation of what the past means for and in the present. This specific mechanism of change is not the only possible theoretical conceptualization of change in and through practice. Duvall and Chowdhury highlight two other possible 'trajectories' of change that complement ours: on the one hand, purposefully 'incompetent' practices by transgressive actors; on the other hand, re-articulations of the relationship between practices and signifiers (2011, 347-351). Duvall and Chowdhury's trajectories are applicable to the case of NATO-Russia relations. Indeed the contestation of whether an action is true to the past can be read as a contestation of a specific form of competence (through the accusation of 'outdatedness'), and it is conceivable that certain acts by Russian or NATO practitioners were purposefully 'incompetent' and subversive. Furthermore, in Pouliot's empirical analysis of post-Cold War politics, the signifier 'security' clearly plays a central role. This signifier is linked to specific pasts: 'internal security' is linked to the end of the Cold War, while 'external security' is linked to its continuation. Through these links, history gains relevance for present practice.

Our account of change as the result of contested actualizations of the past does not represent a comprehensive theory of how international practices change. One can conceive of other mechanisms or 'trajectories', some complimentary, others alternative to what we have proposed. Our aim has been to elaborate one mechanism of change that has so far not been clearly articulated by IR practice theorists, even though the importance of this mechanism is clearly evident in international security practices after 
the end of the Cold War. In order to understand the instability of these practices, one needs to understand how they relate to the past.

\section{Conclusion}

Practices of international security after the end of the Cold War are inherently unstable and contested, because there is no certainty about whether the Cold War with its logic of bipolar confrontation has ended once and for all, or whether it lives on in the attitudes and habits of practitioners of international security. This contestedness of the past has very real con- sequences for the present. It destabilizes present practices and thus makes sudden and drastic change possible. The theoretical question that occupied Mearsheimer and Wendt in the early 1990s, whether the events of 1989 heralded a false promise or marked a deep normative transformation of the international system, thus also occupied those who practice international security. ${ }^{14}$ And as the recent events in the Ukraine demonstrate in the most dramatic fashion, this question still very much occupies security practitioners today. The uncertainty these debates produce about the consequences of 1989 is itself a source of change in and through practice.

If one assumes with Bourdieu that international order is sustained through the relative durability of habitus, that is, of deeply internalized dispositions formed by past experience, the continuing instability and contestation of post-Cold War security practices is puzzling. Conceptualized with the Bourdieusian notion of habitus, international politics appears as conditioned by one single, clearly discernible structure. Within the Bourdieusian framework, it is conceivable that certain actors, due to shifts that are not explained by the theory itself, come to carry dispositions that are not aligned with the prevailing structures. Like Don Quixote, these actors display behavior that is clearly out of sync with reality. In theory, it is conceivable that their ill-adapted behavior destabilizes international structures and effects further change. In practice, however, we did not find one clearly dominant (and thus 'objective') structure based on one dominant interpretation of the past. We found that actors held differing views on the same, shared past and that these differences rendered practices unstable.

We think that its widespread reliance on the Bourdieusian notion of habitus is the main reason why international practice theory has so far struggled with the question of change. A case in point is Vincent Pouliot's International Security in Practice. Pouliot's insightful empirical narrative of NATO-Russia relations after the end of the Cold War clearly demonstrates how uncertainty about the consequences of 1989 destabilized

\footnotetext{
${ }^{14}$ For a more general argument about how the same figures of thought structure both the debates of IR and the political practices IR aspires to explain, see Schindler (2014).
} 
international security practices and led to sudden and drastic changes. His Bourdieusian notion of habitus, however, lets Pouliot lose grasp of these insights. In his theoretical interpretations, uncertainties and ambiguities disappear. NATO's acts appear to be naturally in tune with the new order, while Russia struggles to adjust to the realities of post-Cold War politics.

To come to terms with the problem of change, international practice theory needs to move beyond the Bourdieusian model of social reproduction. We have demonstrated the potential of such a move by elaborating a specific mechanism of how change unfolds in and through practice. Drawing on Pouliot's account of practices at the NATO-Russia Council (NRC) in 2004, we have demonstrated that practices can be unstable not only because the actors actualize different pasts, but also because they actualize the same past differently. Through contested actualizations of the past, present practices change.

Our point is not that the meaning of the past is not and never will be settled. Rather, to settle what the past means for the present is a crucial challenge to, and achievement of, all practice. Such settlements are achieved in concrete places and at concrete times. Acts like NATO's enlargement decision or Russia's intervention in Georgia gave new meaning to the end of the Cold War. Such events then become new points of reference for later practice, and more often than not their meaning will itself be uncertain. Change in and through practice is possible because the meaning of the past is open to contestation. Past events never point unequivocally into the future.

\section{Acknowledgements}

The authors are grateful to Bud Duvall, George Lawson, Kristina Lepold, the participants of colloquia at the University of Münster, Goethe University Frankfurt, and the University of Minnesota, as well as to the anonymous reviewers and the editors of IT for their very helpful comments. Furthermore, they would like to thank Vincent Pouliot for his open and constructive engagement with their argument. The authors of this article are listed alphabetically and have contributed equally.

\section{References}

Adler, Emanuel, and Vincent Pouliot, eds. 2011a. International Practices. Cambridge: Cambridge University Press.

Adler, Emanuel, and Vincent Pouliot 2011b. "International Practices." International Theory 3(1):1-36.

Adler-Nissen, Rebecca. 2008. "The Diplomacy of Opting Out: A Bourdieudian Approach to National Integration Strategies." Journal of Common Market Studies 46(3):663-84. 
Adler-Nissen, Rebecca, ed. 2013. Bourdieu in International Relations: Rethinking Key Concepts in IR. Milton Park: Routledge.

Adler-Nissen, Rebecca 2014. "Symbolic Power in European Diplomacy: The Struggle Between National Foreign Services and the EU's External Action Service." Review of International Studies 40(4): 657-681.

Auchter, Jessica. 2014. The Politics of Haunting and Memory in International Relations. London: Routledge.

Badiou, Alain. 2001. Ethics: An Essay on the Understanding of Evil. London: Verso.

Bigo, Didier. 2011. "Pierre Bourdieu and International Relations: Power of Practices, Practices of Power." International Political Sociology 5(3):225-58.

Boltanski, Luc. 2011. On Critique: A Sociology of Emancipation. Cambridge: Polity.

Bourdieu, Pierre. 1977. Outline of a Theory of Practice. Cambridge: Cambridge University Press.

Bourdieu, Pierre 1984. Distinction: A Social Critique of the Judgement of Taste. Cambridge, MA: Harvard University Press.

Bourdieu, Pierre 1988. Homo Academicus. Stanford, CA: Stanford University Press.

Bourdieu, Pierre 1990. The Logic of Practice. Stanford, CA: Stanford University Press.

Bourdieu, Pierre 1996. The State Nobility: Elite Schools in the Field of Power. Stanford, CA: Stanford University Press.

Bourdieu, Pierre, and Jean C. Passeron. 1977. Reproduction in Education, Society and Culture. London: Sage.

Bourdieu, Pierre, and Loic Wacquant. 1989. "Towards a Reflexive Sociology: A Workshop with Pierre Bourdieu." Sociological Theory 7(1):26-63.

Bourdieu, Pierre, and Loic Wacquant 1992. An Invitation to Reflexive Sociology. Cambridge: Polity Press.

Brubaker, Rogers. 1985. "Rethinking Classical Sociology: The Sociological Vision of Pierre Bourdieu." Theory and Society 14(6):745-75.

Bueger, Christian, and Frank Gadinger. forthcoming. "The Play of International Practices." International Studies Quarterly.

Bueger, Christian, and Frank Gadinger 2014. International Practice Theory. Basingstoke: Palgrave Macmillan.

Derrida, Jacques. 1982. “Différance.” In Margins of Philosophy, edited by Alan Bass, 3-27. Chicago, IL: University of Chicago Press. 
Duvall, Raymond D., and Arjun Chowdhury. 2011. "Practices of Theory.” In International Practices, edited by Emanuel Adler, and Vincent Pouliot, 335-54. Cambridge: Cambridge University Press.

Eagleton-Pierce, Matthew. 2011. "Advancing a Reflexive International Relations." Millennium - Journal of International Studies 39(3):805-23.

Eagleton-Pierce, Matthew 2012. Symbolic Power in the World Trade Organization. Oxford: Oxford University Press.

Edkins, Jenny. 2003. Trauma and the Memory of Politics. Cambridge: Cambridge University Press.

French, Brigittine M. 2012. "The Semiotics of Collective Memories." Annual Review of Anthropology 41(1):337-53.

Gheciu, Alexandra. 2005. NATO in the 'New Europe': The Politics of International Socialization after the Cold War. Stanford, CA: Stanford University Press.

Giddens, Anthony. 1984. The Constitution of Society: Outline of the Theory of Structuration. Cambridge: Polity Press.

Giroux, Henry. 1983. "Theories of Reproduction and Resistance in the New Sociology of Education: A Critical Analysis." Harvard Educational Review 53(3):257-93.

Go, Julian. 2008. "Global Fields and Imperial Forms: Field Theory and the British and American Empires." Sociological Theory 26(3):201-29.

Gustafsson, Martin. 2010. "Seeing the Facts and Saying What You Like: Retroactive Redescription and Indeterminacy in the Past." Journal of the Philosophy of History 4(3): 296-327.

Guzzini, Stefano. 2000. "A Reconstruction of Constructivism in International Relations." European Journal of International Relations 6(2):147-82.

Hacking, Ian. 1995. Rewriting the Soul: Multiple Personality and the Sciences of Memory. Princeton, NJ: Princeton University Press.

Halbwachs, Maurice. 1992. On Collective Memory, Translated by Lewis A. Coser. Chicago, IL: University of Chicago Press.

Hamati-Ataya, Inanna. 2013. “Reflectivity, Reflexivity, Reflexivism: IR's 'Reflexive Turn' and Beyond." European Journal of International Relations 19(4):669-94.

Hansen, Lene. 2011. "Performing Practices: A Poststructuralist Analysis of the Muhammad Cartoon Crisis." In International Practices, edited by Emanuel Adler, and Vincent Pouliot, 280-309. Cambridge: Cambridge University Press. 
Harker, Richard K. 1984. “On Reproduction, Habitus and Education.” British Journal of Sociology of Education 5(2):117-27.

Hopf, Ted. 2010. "The Logic of Habit in International Relations." European Journal of International Relations 16(4):539-61.

Jackson, Peter. 2008. "Pierre Bourdieu, the 'Cultural Turn' and the Practice of International History." Review of International Studies 34(1):155-81.

King, Anthony. 2000. "Thinking with Bourdieu against Bourdieu: A 'Practical' Critique of the Habitus." Sociological Theory 18(3):417-33.

Koslowski, Rey, and Friedrich V. Kratochwil. 1994. "Understanding Change in International Politics: The Soviet Empire's Demise and the International System." International Organization 48(2):215-47.

Kuus, Merje. 2014. Geopolitics and Expertise: Knowledge and Authority in European Diplomacy. Chichester: John Wiley \& Sons.

Lawson, George. 2010. “Introduction: The 'What', 'When' and 'Where' of the Global 1989.” In The Global 1989: Continuity and Change in World Politics, edited by George Lawson, Chris Armbruster, and Michael Cox. Cambridge: Cambridge University Press.

Leander, Anna. 2002. “Do We Really Need Reflexivity in IPE? Bourdieu's Two Reasons for Answering Affirmatively." Review of International Political Economy 9(4):601-09.

Leander, Anna 2008. “Thinking Tools.” In Qualitative Methods in International Relations: A Pluralist Guide, edited by Audie Klotz, and Deepa Prakash, 11-27. Basingstoke: Palgrave Macmillan.

Leander, Anna 2011. "The Promises, Problems, and Potentials of a Bourdieu-Inspired Staging of Inter- national Relations." International Political Sociology 5(3):294-313.

Lebow, Richard N. 1994. "The Long Peace, the End of the Cold War, and the Failure of Realism." International Organization 48(2):249-77.

Lundborg, Tom. 2012. Politics of the Event: Time, Movement, Becoming. London: Routledge. Mearsheimer, John J. 1994. “The False Promise of International Institutions.” International Security 19(3):5-49.

Mérand, Frédéric. 2010. "Pierre Bourdieu and the Birth of European Defense." Security Studies 19(2):342-74.

Neumann, Iver B. 2002. "Returning Practice to the Linguistic Turn: The Case of Diplomacy.” Millennium - Journal of International Studies 31(3):627-51.

Neumann, Iver B. 2012. “Euro-Centric Diplomacy: Challenging but Manageable.” European Journal of International Relations 18(2):299-321. 
Neumann, Iver B., and Vincent Pouliot. 2011. "Untimely Russia: Hysteresis in RussianWestern Relations over the Past Millennium." Security Studies 20(1):105-37.

Nora, Pierre. 1989. "Between Memory and History: Les Lieux de Mémoire." Representations 26:7-24.

Pouliot, Vincent. 2007. “'Sobjectivism': Toward a Constructivist Methodology." International Studies Quarterly 51(2):359-84.

Pouliot, Vincent 2008. "The Logic of Practicality: A Theory of Practice of Security Communities." Inter- national Organization 62(2):257-88.

Pouliot, Vincent 2010. International Security in Practice: The Politics of NATO-Russia Diplomacy. Cambridge: Cambridge University Press.

Pouliot, Vincent, and Frédéric Mérand. 2013. “Bourdieu's Concepts: Political Sociology in International Relations." In Bourdieu in International Relations: Rethinking Key Concepts in IR, edited by Rebecca Adler-Nissen, 24-44. Milton Park: Routledge.

Ringmar, Erik. 2014. “The Search for Dialogue as a Hindrance to Understanding: Practices as Inter-Paradigmatic Research Program." International Theory 6(1):1-27.

Roth, Paul A. 2012. “The Pasts." History and Theory 51(3):313-39.

Sahlins, Marshall. 1981. Historical Metaphors and Mythical Realities: Structure in the Early History of the Sandwich Islands Kingdom. Ann Arbor, MI: University of Michigan Press.

Sahlins, Marshall 1985. Islands of History. Chicago, IL: University of Chicago Press.

Schindler, Sebastian. 2014. "Man versus State: Contested Agency in the United Nations." Millennium - Journal of International Studies 43(1):3-23.

Sewell, William H. 2005. Logics of History: Social Theory and Social Transformation. Chicago, IL: University of Chicago Press.

Shapiro, Michael J. 2002. "Bourdieu, the State and Method." Review of International Political Economy 9(4):610-18.

Swartz, David. 1997. Culture and Power: The Sociology of Pierre Bourdieu. Chicago, IL: University of Chicago Press.

Villumsen Berling, Trine. 2012. "Bourdieu, International Relations, and European Security." Theory and Society 41(5):451-78.

Walt, Stephen M. 1997. "The Gorbachev Interlude and International Relations Theory." Diplomatic History 21(3):473-79.

Wendt, Alexander. 1987. "The Agent-Structure Problem in International Relations Theory." International Organization 41(3):335-70. 
Wendt, Alexander 1992. "Anarchy is What States Make of it: The Social Construction of Power Politics." International Organization 46(2):391-425.

Wight, Colin. 2006. Agents, Structures and International Relations: Politics as Ontology. Cambridge: Cambridge University Press.

Williams, Michael C. 2007. Culture and Security: Symbolic Power and the Politics of International Security. Milton Park: Routledge.

Wohlforth, William C. 1994. "Realism and the End of the Cold War." International Security 19(3):91-129.

Zehfuss, Maja. 2007. Wounds of Memory: The Politics of War in Germany. Cambridge: Cambridge University Press. 